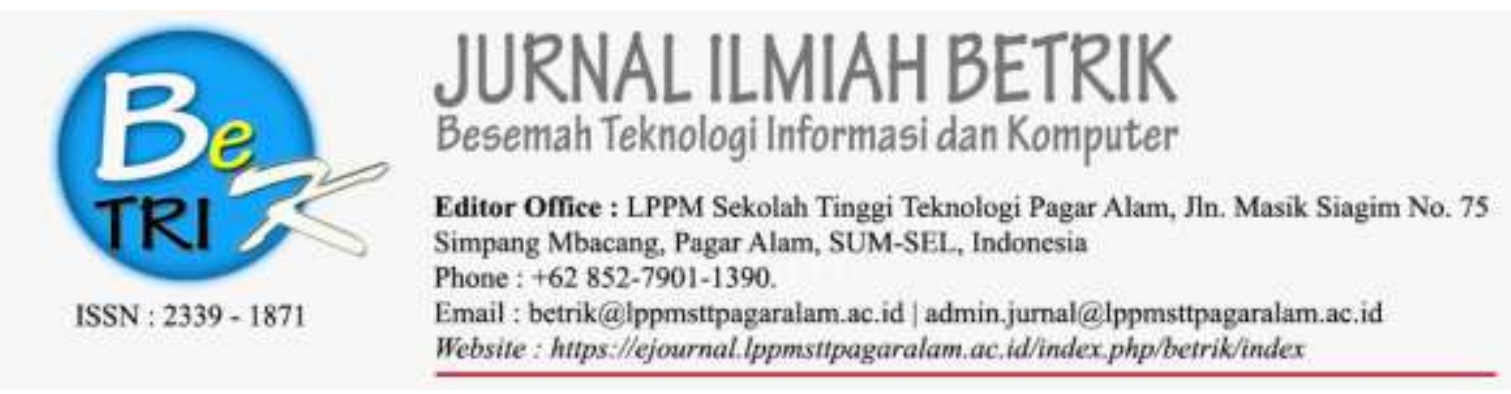

\title{
RANCANG BANGUN SEWA KONTRAK KIOS PASAR DEMPO PERMAI KOTA PAGAR ALAM BERBASIS WEB
}

\author{
Sasmita \\ Dosen Sekolah Tinggi Teknologi Pagar Alam \\ Jln. Masik Siagim No. 75 Simpang Mbacang Dempo Tengah Kota Pagar Alam \\ Sur-el:sasmitha661@gmail.com
}

\begin{abstract}
Currently the progress of Information and Communication Technology has been adapted by various government agencies or private, one of the technology that can be used is web, government have used this technology for e-government. The Office of Industry, Trade and SME of Kota Pagar Alam that runs the Market through the Technical Implementation Unit of the Service gives the right to rent at Pasar Dempo Pagar Alam. During this time if there is an empty kiosk, prospective tenants come to the clerk for confirmation and lease submission process. To simplify the management and lease submission process, an application is needed that can facilitate the officer and prospective tenants to interact, while the application will be built is web-based. The purpose of this study design application in the sense of translating the results of the analysis into the form of software packages later Create the system or improve the existing system. To make the proposed system the author uses the steps of Customer Communication, planning, modeling, construction and deployment.
\end{abstract}

Keywords: Website, e-government, php, Mysql

\begin{abstract}
Abstrak: Saat ini kemajuan Teknologi Informasi dan Komunikasi telah diadaptasi oleh berbagai instansi pemerintah ataupun swasta, salah satu teknologi yang dapat digunakan adalah web, pemerintah telah menggunakan teknologi ini untuk e-government. Dinas Perindustrian, Perdagangan dan UKM Kota Pagar Alam yang mengelola Pasar melalui Unit Pelaksana Teknis Dinas memberikan hak sewa di Pasar Dempo Pagar Alam. Selama ini jika ada kios yang kosong, calon penyewa mendatangi petugas untuk konfirmasi dan proses pengajuan sewa. Untuk mempermudah dalam pengelolaan dan proses pengajuan sewa, diperlukan aplikasi yang dapat mempermudah petugas dan calon penyewa untuk berinteraksi, adapun aplikasi yang akan dibangun adalah berbasis web.Tujuan dalam penelitian ini rancang bangun aplikasi dalam arti kegiatan menerjemahkan hasil analisa ke dalam bentuk paket perangkat lunak kemudian menciptakan sistem tersebut ataupun memperbaiki sistem yang sudah ada. Untuk membuat sistem yang diusulkan penulis menggunakan langkah Customer Communication, planning, modelling, construction dan deployment.
\end{abstract}

Kata kunci : Website, e-government, php, Mysql 


\section{PENDAHULUAN}

Teknologi informasi dan komunikasi telah berkembang dengan pesat, hal ini akan membawa perubahan dalam pemikiran dan sikap. Perubahan dalam pemikiran adalah keinginan untuk beradaptasi dengan kemajuan teknologi sehingga dapat memberikan penilaian akhir yang berpengaruh pada sikap untuk menggunakan teknologi atau tidak menggunakan guna menunjang kehidupan sehari-hari.

Web Site merupakan salah satu produk dari inovasi dalam bidang Teknologi Infomasi dan Komunikasi, Tim Bernass Lee yang pertama kali mempelopori dengan mengembangkan bahasa pemrograman HTML dan dilanjutkan oleh para ahli lainnya sehingga kita mengenal web saat ini yang sangat dinamis.

Pemerintah telah mengadopsi kemajuan teknologi web dengan adanya e-government, salah satu buktinya adalah aplikasi layanan pengadaan secara elektronik (LPSE) Pagar Alam yangdapat diakses

di
http://lpse.pagaralam.go.id. Para pemborong yang akan melakukan tawar-menawar lelang dapat dilakukan melalui web tersebut. Begitu juga dengan penyewaann kios dipasar dempo permai, saat ini calon penyewa mencari sendiri informasi tentang kios yang kosong, kemudian menghadap petugas UPTD atau langsung ke kantor Deprindagkop UKM untuk melakukan konfirmasi dan penyewaan kios tersebut. Menurut hemat saya hal ini terlalu mempersulit calon penyewa, yang hanya sekedar untuk mendapatkan surat izin menggunakan tempat. Langkah selama ini calon penyewa selalu mencari sendiri tempat yang akan disewa, jika ada tempat kosong, calon penyewa menghubungi petugas untuk melakukan pemeriksaan status kios tersebut.

Untuk itu penulis ingin mengembangkan aplikasi berbasis web untuk mempermudah calon penyewa untuk mengetahui kios yang kosong, melakukan pengajuan untuk menjadi calon penyewa, setelah disetujui dan diketahui jumlah sewa yang harus dibayar maka calon pembeli melakukan pembayaran dan konfirmasi untuk melakukan pencetakan surat izin penggunaan. Adapun judul yang akan diambil dalam penelitian ini adalah" Rancang Bangun Sewa Kontrak Kios Pasar Dempo Permai Kota Pagar Alam Berbasis Web".

\section{METODOLOGI PENELITIAN}

\subsection{Metodologi Penelitian}

Pressman (2010: 17), menyusun suatu sistem yang baru untuk menggantikan sistem yang lama secara keseluruhan atau memperbaiki sistem yang telah berjalan. Pengembangan sistem ini metode pengembangan menggunakan menggunakan Web Engineering, karena metode ini memberikan ide bagi pengembang maupun user tentang cara sistem akan berfungsi dan yang akan dikembangkan.

\subsection{Analisa Rekayasa Web}

\subsubsection{Sistem yang sedang berjalan}

Pada sistem yang saat ini sedang berjalan saat ini Jika seseorang akan menyewa kios di Pasar Dempo Permai, calon penyewa dapat mencari kios yang kosong dan tidak digunakan atau diperpanjang sewanya. Jika sudah menemukan lokasi yang cocok, calon penyewa menemui petugas pengelola pasar atau langsung ke Dinas Perindagkop UKM dan Pengelolaan 
Pasar Kota Pagar Alam. Jika digambarkan maka use case diagram sistem yang sedang berjalan sebagai berikut:

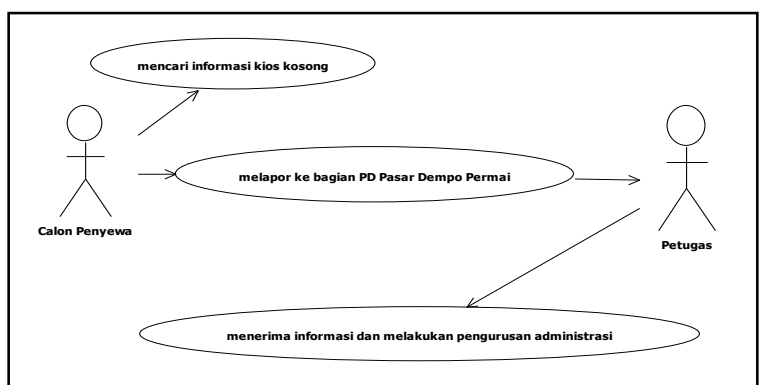

Gambar 1.Sistem Berjalan

\subsubsection{Sistem Usulan}

Untuk merancang sistem yang akan diusulkan dalam penelitian ini, penulis menggunakan use case diagram untuk mempermudah dalam menjelaskan rancangan sistem. Aktor yang akan digunakan adalah admin dan calon penyewa yang akan berinteraksi melalui sarana web. Untuk lebih jelasnya perhatikan gambar di bawah ini:

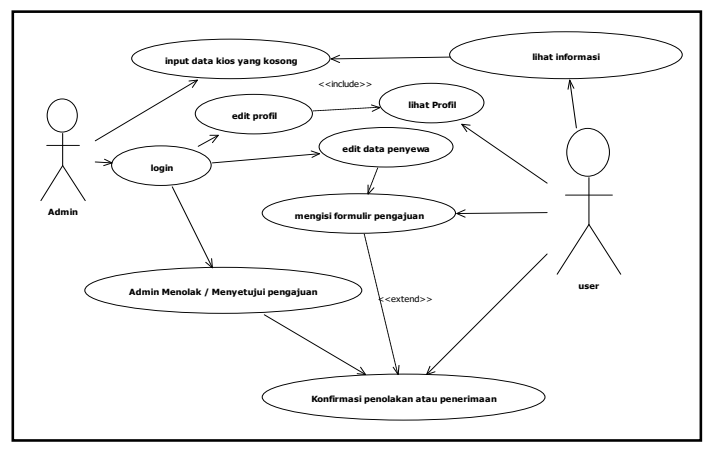

Gambar 2. Sistem Usulan

\subsection{Rancangan Website}

\subsubsection{Rancangan Menu Utama}

Rancangan menu utama merupakan indek dari web yang akan dikembangkan, halaman inilah yang akan terlebih dahulu berhadapan dengan user. Adapun rencana tampilan halaman utama sebagai berikut :

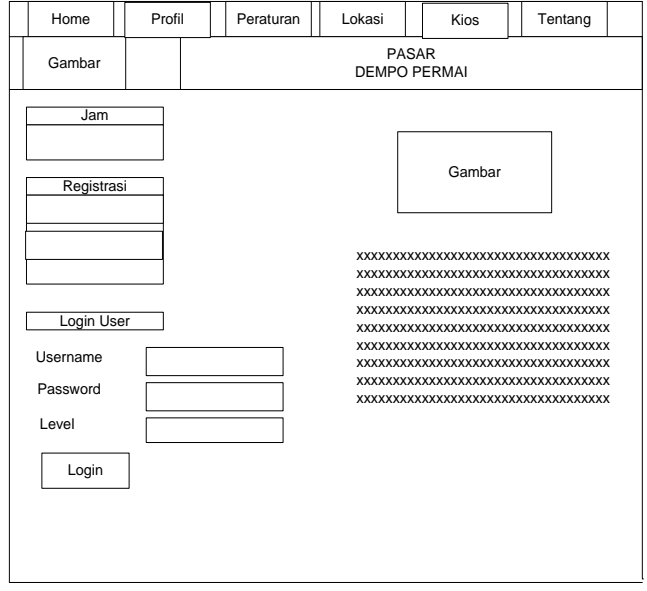

Gambar 3.Rancangan Menu Utama

\subsubsection{Rancangan Diagram Sistem Kenaikan}

\section{Gaji Berkala Badan Kepegawaian} Daerah Kota Pagar Alam.

Rancangan Sistem Kenaikan Gaji Berkala Badan Kepegawaian Daerah Kota Pagar Alam, menggambarkan interaksi antara Pegawai dengan sistem yang dibuat. Use Case ini dapat diketahui proses yang terjadi pada aktivitas yang berjalan. Berikut adalah gambar rancangan Sistem Kenaikan Gaji Berkala Badan Kepegawaian Kota Pagar Alam.

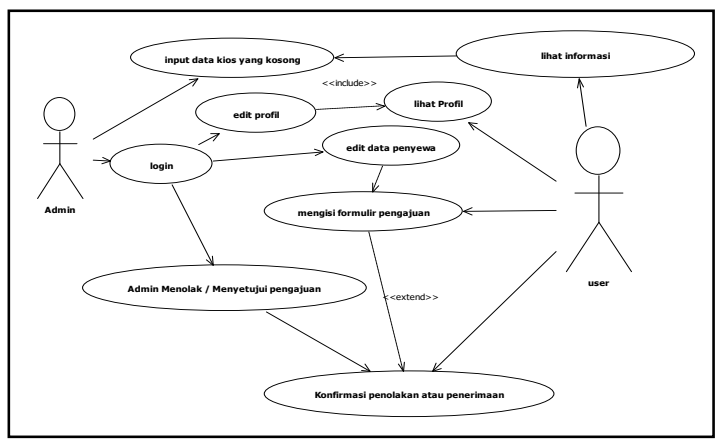

Gambar4.Rancangan Diagram Sistem

\subsubsection{Rancangan Activity Diagram Admin}

Activity Diagram Admin, berfungsi untuk sistem keamanan sehingga untuk bisa mengakses data harus melakukan login terlebih dahulu. Ketika melakukan login sistem memvalidasi data login benar atau salah dalam 
menginputkan data. Setelah data sukses sistem masuk pada halaman utama admin, yang dapat dilihat pada gambar di bawah ini:

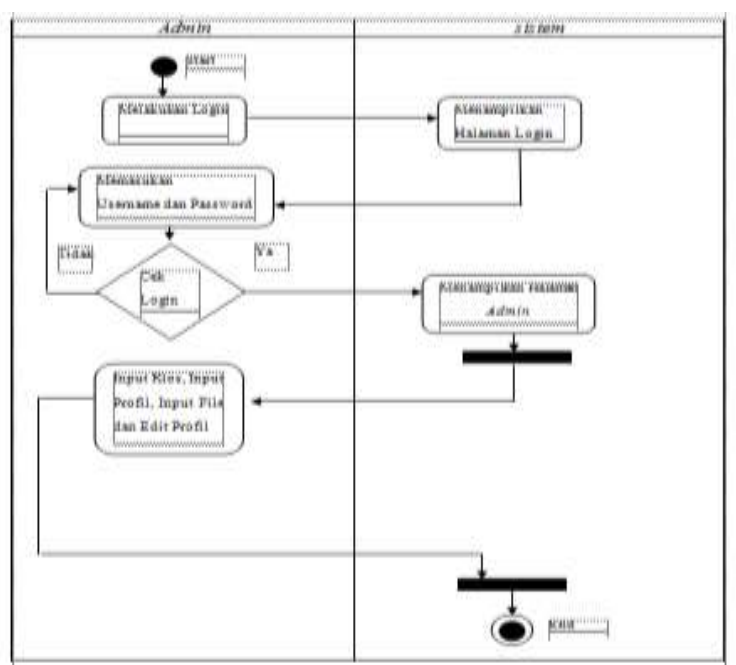

Gambar 5.Activity Diagram Admin

\subsubsection{Rancangan Activity Diagram User}

Activity Diagram User menggambarkan tahapan interaksi antara user ke dalam sistem dimana User ingin melakukan pembukaan web harus login terlebih dahulu dengan memasukan username dan password yang benar setelah itu akan masuk ke halaman user. Halaman user terdiri dari menu pengajuan sewa, melihat status pengajuan dan mencetak bukti pendaftaran jika pengajuan sudah diterima oleh admin. Rancangan Activity diagram user adalah sebahai berikut :

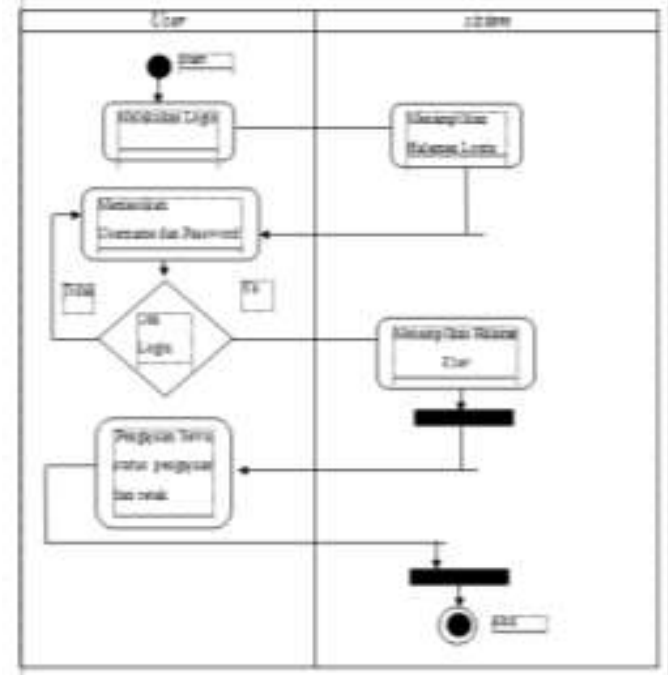

Gambar 6. Activity Diagram User

\subsection{Diagram Squency Diagram Admin}

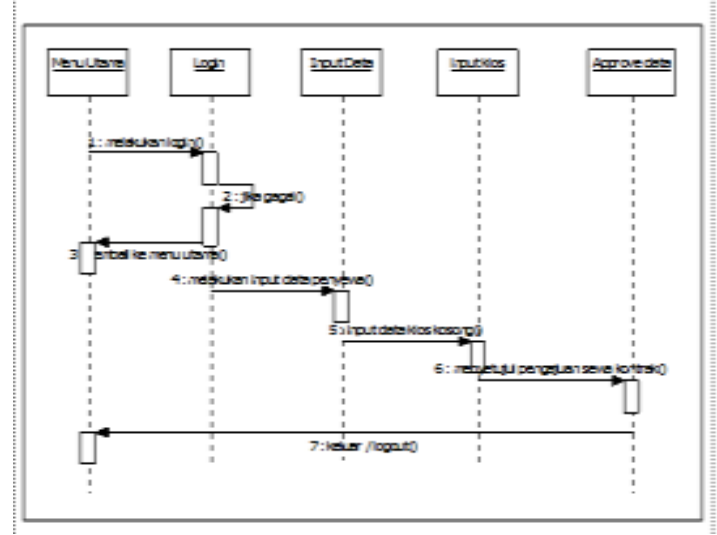

Gambar 9. Squency Diagram Admin

\subsection{Diagram Squency Diagram User}

Menggambarakan Intraksi antara user dengan sistem di sini user panggil menu web maka sistem menampilkan home user kemudian user mencari dan melihat data. jika tidak ada user, akan keluar dari web. 


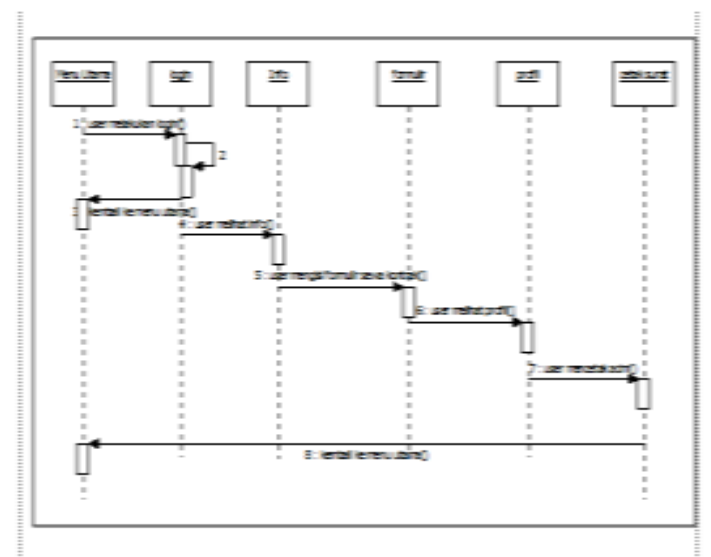

Gambar 10.Squency User User

\subsection{Class Diagram Admin}

Class diagram menggambarkan struktur dan deksripsi class, package dan object serta hubungan satu sama lain. Class diagram terdiri dari relasi beberapa class, dalam class itu sendiri terdiri dari atributte dan operation yang menggambarkan keadaan suatu sistem yang menawarkan layanan untuk memanipulasi keadaan tersebut (metoda/fungsi).

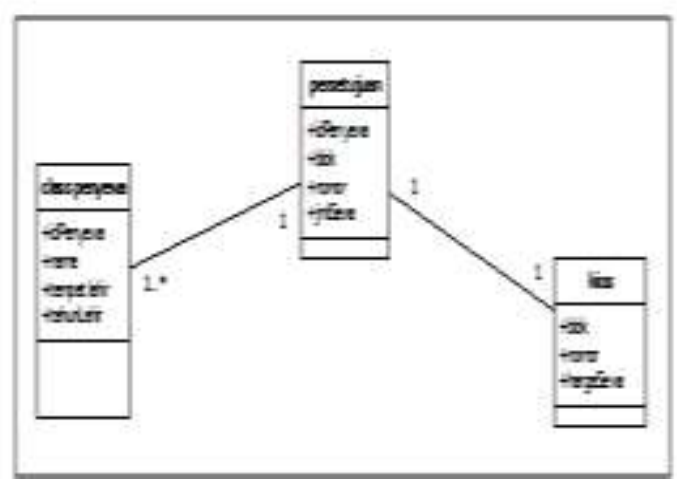

Gambar 13. Class Diagram

\subsection{Rancangan Halaman Menu Utama}

Halaman utama merupakan halaman awal yang ditampilkan pada saat user membuka Website. Tampilan halaman utama dapat dilihat pada Gambar di bawah ini:

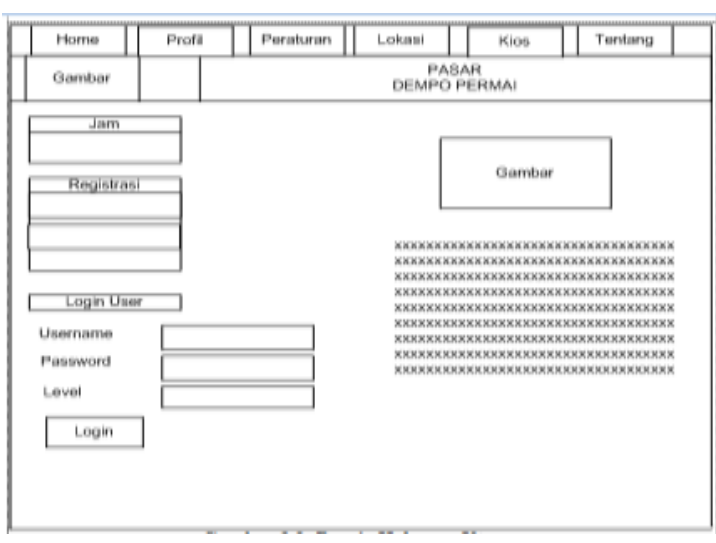

Gambar 14. Rancangan Tampilan Halaman Utama

\section{HASIL}

\subsection{Hasil}

Menu utama adalah tampilan awal ketika kita membuka Website yang terdiri dari menu home, profil, peraturan, lokasi kios dan tentang yang dapat dilihat pada gambar 15 dibawah ini:

\subsubsection{Halaman Login}

Halaman Login adalah halaman yang digunakan user dan admin untuk masuk kedalam halaman mereka masing-masing, halaman login yang dapat dilihat pada gambar di bawah ini:

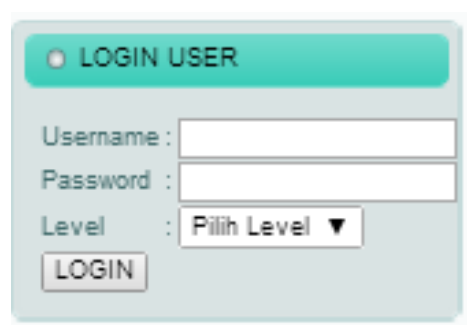

\section{Gambar 15. Halaman Login}

\subsubsection{Menu Utama}

Menu utama adalah tampilan awal ketika kita membuka Website Badan Kepegawaian Daerah Kota Pagar Alam yang terdiri dari menu home, profil, informasi,berita,galeri dan buku tamu yang dapat dilihat pada gambar 16 dibawah ini: 


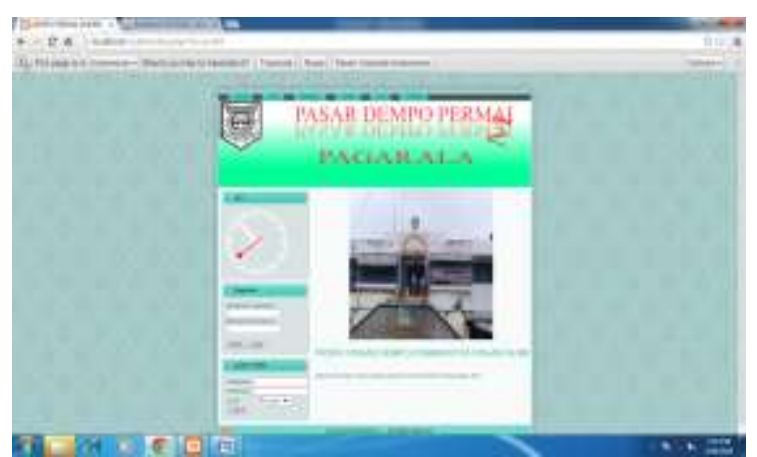

Gambar 16. Menu Utama

\subsubsection{Halaman Admin}

Halaman Admin untuk mengelola data seperti input data dan lihat data. Halaman admin dapat kita lihat seperti gambar dibawah ini :

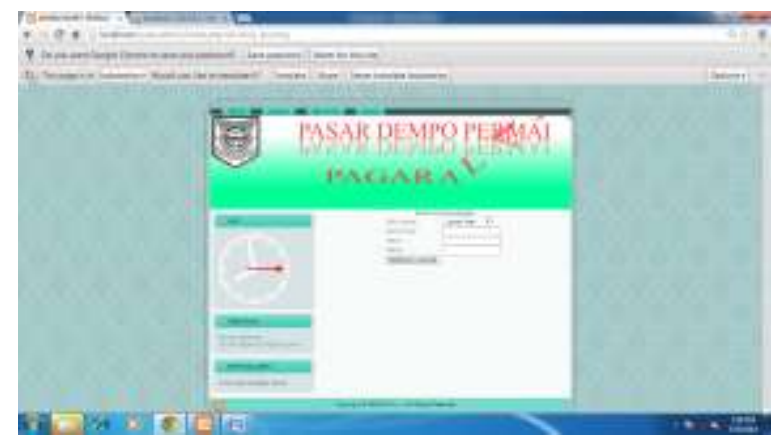

Gambar 17. Halaman Admin

\subsubsection{Menu Admin Input Data Profil}

Pada Halaman ini akan ditampilkan mengenai data Profil yang akan menginput data profil tersebut guna mencari data profil web tersebut, menu Admin input data profil dapat kita lihat seperti dibawah ini :

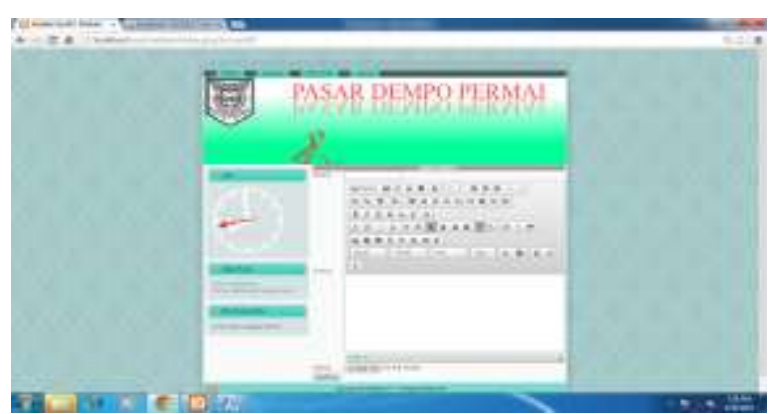

Gambar 18.Menu Admin Input data Profil
Menu input file ini digunakan untuk admin menginputkan file denah dempo permai dan peraturanya, menu admin input file dapat kita lihat seperti gambar dibawah ini :

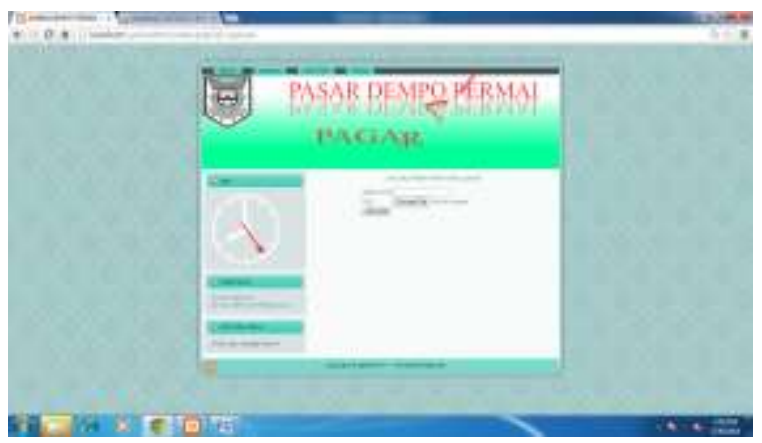

Gambar 19. Menu Admin Input file

\subsubsection{Halaman Output Data Kios Kosong}

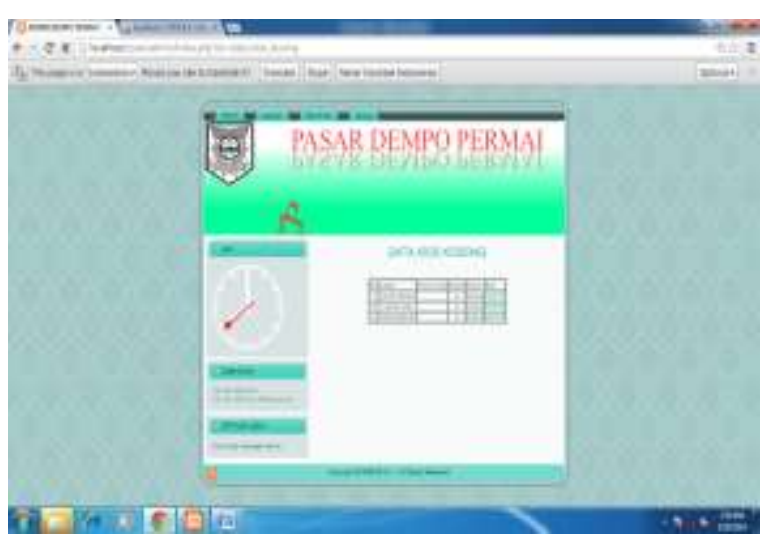

Gambar 20. Output Data Kios Kosong

\section{SIMPULAN}

Berdasarkan dari hasil penelitian yang telah dilakukan, maka peneliti menyimpulkan bahwa:

1. Membangun sebuah situs membutuhkan waktu yang cukup lama terutama dalam tahap desain tampilan, karena tampilan yang menarik sangat diperlukan dalam merancang sebuah sistem informasi agar para user nyaman menelusuri website ini.

2. Dibutuhkan ketelitian dan keakuratan dalam merancang tabel dan alir data khususnya membuat situs.

\subsubsection{Menu Admin Input File}


3. Penguasaan dalam penggunaan editor dan bahasa pemrograman yang mendukung akan mempermudah dalam pengerjaan.

4. Perancangan database juga diperlukan ketelitian untuk mempermudah dalam mengelola keluar masuk data, menghapus data yang tidak dibutuhkan lagi.

\section{RUJUKAN}

Ladjamudin. 2005. Analisis dan Desain Sistem Informasi. Yogyakarta : Graha Ilmu.

Peranginangin, Kasiman. 2006. Aplikasi

Web dengan PHP dan MySQL. Yogyakarta : Andi.

Peraturan Pemerintah No. 16 Tentang Pasar Dempo Permai

Pressman RS. 2002. Rekayasa Perangkat Lunak Pendekatan Praktisi (Buku Satu).

Yogyakarta: Andi.

Sumarta, T. Perancangan Model Berorientasi Objek Menggunakan Unified Modeling Language(UML) Studi Kasus Sistem Pengolahan Parkir Pada PT. TRIKARYA

$A B A D I$. diunduh dari http://gunadarma.ac.id Tanggal 1

Desember 2013.

Suryanto, Asep Herman. 2009. Step by Step Web Design: Theory ang Practices.

Yogyakarta: Penerbit Andi

Whitten JL et.All. 2004. System Analysis and Design Methods. Diterjemahkan oleh: Tim Penerjemah Andi. Yogyakarta: Andi. 
